\title{
An Analysis of Actual Conditions with the Infectious Disease of Middle East Respiratory Syndrome Coronavirus (MERS-CoV) Spreading in South Korea
}

\author{
Gyu-Yil Choi ${ }^{1}$ and Sang-Sub Park ${ }^{2 *}$ \\ 'Department Dental Hygiene, ChungCheong University, Korea; edugy@hanmail.net \\ ${ }^{2}$ Department Emergency Medical Technology, ChungCheong University, Korea; wooonseo@hanmail.net
}

\begin{abstract}
Back ground / Objectives: The purpose of this study was to identify problems with infectious diseases on the basis of the spread of Middle East Respiratory Syndrome Corona virus (MERS-CoV). Methods/ Statistical Analysis: For this purpose, the data from the Korea Centers for Disease Control and Prevention (CDC) and the Ministry of Health and Welfare (MOHW) were coded on the basis of daily briefing. A total of 186 persons were diagnosed with MERS. The duration of MERS outbreak in South Korea was from May 20, 2015 to July 28, 2015, when the cessation of the disease was first announced. Analysis was performed using SPSS for Windows 12.0 Version. Findings: Of the 186 persons diagnosed with MERS, 36 died, 12 were under treatment, and 138 leave hospital. There were 5 super-spreaders: the index case \#1, \#14, \#15, \#16, and \#76. The five super-spreaders made more than a half of all the MERS patients infected with the disease. An infectious disease can mean a medical disaster. To prevent such a disaster, it is necessary to make thorough personal hygiene management and institutional program reinforcement. Application/Improvements: It is also necessary to develop systematic management systems that involve planning, implementation, restoration, and prevention with the aim of coping with outbreak of a disaster with an infectious disease.
\end{abstract}

Keywords: Disaster, Index Case, Infection, MERS-CoV, Spreading

\section{Introduction}

The World Health Organization $(\mathrm{WHO})^{1}$ reported that MERS is a viral respiratory disease caused by corona virus, which broke out in Saudi Arabia in ${ }^{2}$ reported that an unknown type of corona virus was isolated from phlegm for pneumonia and renal failure. They indicated that the corona virus was associated with bats. $\mathrm{In}^{3}$ reported that it was associated with the contact with camels. $\mathrm{In}^{4}$, found that MERS has such symptoms as fever, cough, and difficulty in breathing and can even cause pneumonia.

According to $\mathrm{WHO}^{1} 26$ countries, including Saudi Arabia, reported MERS outbreak. South Korea is also one of the 26 countries. According to $\mathrm{CDC}^{5}$, the index case is a man in his sixties. He showed such symptoms as fever and cough after he returned from Bahrain on May 4, 2015. He was diagnosed with MERS on May 20, 2015.

When the index case of MERS appeared in South Korea, the central government and people had low awareness of the hazard of the disease. In the initial briefing, the healthcare authorities failed to provide clear information about its spread, infection channels, infection sites, mortality, and prevention and refused to disclose the list of relevant hospitals. As a result, some people in the same room or ward as the index case-including inpatients, visitors, doctors, and nurses-were infected with MERS.

The rapid spread of Middle East Respiratory Syndrome (MERS) has brought changes to the daily life since May 20, 2015. The changes included closure of educational institutions, reduction in hospital visit, indi-

${ }^{*}$ Author for correspondence 
viduals' wearing a mask, etiquette related to coughing, hospital-visiting culture, reduction of places crowded with people, and changes in the tourism industry. There were also changes in the awareness of disasters. Disasters are divided into the surgery-related ones, including building collapse, fire, explosion, and traffic accidents, and the ones related to internal medicine, which involve infectious diseases. The infectious disease of MERS caused a disaster related to internal medicine and has changed awareness of disasters caused by infection in internal medicine.

This study aimed to identify problems with infectious diseases on the basis of the spread of MERS in South Korea, give information about infection sites, infection channels, and the characteristics of super-spreaders, help make prevention, planning, and management related to very dangerous viruses and maintain a healthy life and improve the quality of life in the presence of other dangerous infectious diseases, and provide basic data that could help develop infectious disease programs.

\section{Research Methods}

\subsection{Research Tools}

This study was conducted on the duration of MERS outbreak from May 20 to July 28, 2015. The data came from $\mathrm{CDC}^{6}$ and $\mathrm{MOHW}^{7}$ that reported on daily status. The data released by the Korean Broadcasting System (KBS) ${ }^{8}$ supervising disaster broadcasting at the national level in South Korea were used. The daily status was based on briefing made by governmental bodies every morning. The briefing included MERS status of last day. The contents of MERS-related briefing were also posted on the homepages of CDC and MOHW. The daily status included such items as gender, age, the date of diagnosis, latent period, infection sites, spreaders, patient division, underlying disease, and patients' condition.

The underlying diseases for the dead were anatomically and physiologically classified. They were systematically classified into respiratory, cardiovascular, endocrine, neural, and urologic diseases, malignant tumor, and others. Underlying diseases were identified in the cases of death according to anatomical, physiological, and systematic classification.

The South Korean government made a report on the initial outbreak of MERS on May 20, 2015. The data concerning the daily status of MERS, as released by $\mathrm{CDC}^{6}$ and $\mathrm{MOHW}^{7}$, and those concerning the status of MERS, as released by $\mathrm{KBS}^{8}$, after the report, were collected. The data were divided in terms of the general characteristics, status of MERS, and super-spreaders. The period until the first declaration of the end to MERS outbreak on July 28, 2015 was coded.

186 persons were diagnosed with MERS from May 20 to July 28,2015 . Of the 186 persons diagnosed with MERS, 36 died, 12 were under treatment, and 138 leave hospital during this period. MERS-related briefing was coded and analyzed on the basis of those diagnosed with the disease on a daily basis.

If information about the patients who were dead, who were under treatment, and who leave hospital was missing or failed to have details, the data from the broadcasting system in charge of national disasters - the Korean Broadcasting System $(\mathrm{KBS})^{8}$ - were referred. Analysis was performed using SPSS for Windows 12.0 Version.

The general characteristics of MERS patients are presented in Table 1. Of the 186 patients, males (59.7\%) were more likely to get infected with MERS than females $(40.3 \%)$. Males in their fifties (14.0\%) and females in their sixties (8.6\%) were more likely to get infected with MERS. Older age groups were more likely to get infected with MERS.

\subsection{Analysis}

The contents of MERS-related briefing were coded on the basis of daily status before analysis. Coding was based on the socio-demographic characteristics and the characteristics of MERS. Analysis was performed using SPSS for Windows 12.0 Version.

Table 1. Characteristics of general

\begin{tabular}{|c|c|c|c|}
\hline \multicolumn{2}{|c|}{} & \multicolumn{2}{c|}{ Gender (N: 186) } \\
\cline { 2 - 4 } & 10's & $1(0.5)$ & - \\
\hline \multirow{4}{*}{ Age } & 20 's & $4(2.2)$ & $9(4.8)$ \\
\cline { 2 - 4 } & 30's & $18(9.7)$ & $8(4.3)$ \\
\cline { 2 - 4 } & 40 's & $19(10.2)$ & $11(5.9)$ \\
\cline { 2 - 4 } & 50 's & $26(14.0)$ & $14(7.5)$ \\
\cline { 2 - 4 } & 60 's & $21(11.3)$ & $16(8.6)$ \\
\cline { 2 - 4 } & 70 's & $17(9.1)$ & $13(7.0)$ \\
\cline { 2 - 4 } & 80's $\leq$ & $5(2.7)$ & $4(2.2)$ \\
\hline
\end{tabular}




\section{Results}

\subsection{MERS Infection Status by Gender}

The MERS status by gender is presented in Table 2. As for the infection stage, both males $(40.3 \%)$ and females (26.3\%) were more likely to be third infection cases. As for patients' conditions, there were more leaves from hospital than deaths. However, the mortality rate was $19.4 \%$ (36 out of 186 MERS patients): $12.9 \%$ for males and 6.5\% for females.

Of the MERS patients, both males (51.6\%) and females (27.4\%) were more likely to be ordinary persons. Taking into account the fact that doctors and nurses examining and caring for patients were more vulnerable to MERS infection, it is necessary to prevent hospital workers from the infection.

The latent period of MERS was \pm 11.36 days on average. The period between MERS diagnosis and death for the MERS patients was \pm 9.30 days on average. The period between MERS diagnosis and leave from hospital for the MERS patients was \pm 15.67 days on average.

Table 2. MERS infection status by gender

\begin{tabular}{|c|c|c|c|}
\hline & \multicolumn{2}{|c|}{ Gender(N: 186) } \\
\hline & & Male(N: 111) & Female(N: 75) \\
\hline \multirow{5}{*}{$\begin{array}{l}\text { Infection } \\
\text { stage }\end{array}$} & Initial infection & $1(0.5)$ & - \\
\hline & $\begin{array}{l}\text { Secondary } \\
\text { infection }\end{array}$ & $17(9.1)$ & $13(7.0)$ \\
\hline & Third infection & $75(40.3)$ & $49(26.3)$ \\
\hline & Fourth infection & $14(7.5)$ & $9(4.8)$ \\
\hline & Unidentified & $4(2.2)$ & $4(2.2)$ \\
\hline \multirow{3}{*}{$\begin{array}{l}\text { Patient's } \\
\text { condition }\end{array}$} & Death & $24(12.9)$ & $12(6.5)$ \\
\hline & Leave hospital & $77(41.4)$ & $61(32.8)$ \\
\hline & Treatment & $10(5.4)$ & $2(1.1)$ \\
\hline \multirow{4}{*}{$\begin{array}{l}\text { Patient } \\
\text { division }\end{array}$} & Ordinary person & $96(51.6)$ & $51(27.4)$ \\
\hline & Doctor/Nurse & $7(3.8)$ & $16(8.6)$ \\
\hline & Caregiver & - & $8(4.3)$ \\
\hline & Medical assistant & $8(4.3)$ & - \\
\hline Latent period & & \multicolumn{2}{|c|}{ \pm 11.36 days } \\
\hline $\begin{array}{c}\text { Date of death } \\
\text { after official } \\
\text { diagnosis }\end{array}$ & & \multicolumn{2}{|c|}{ \pm 9.30 days } \\
\hline $\begin{array}{c}\text { Date of Leave } \\
\text { hospital } \\
\text { after official } \\
\text { diagnosis }\end{array}$ & & \multicolumn{2}{|c|}{ \pm 15.67 days } \\
\hline
\end{tabular}

Some cases were "unidentified" in terms of the infection stage; thus, the healthcare authorities were poor at MERS path analysis and management.

\subsection{MERS Infection Status by Patients' Conditions}

The MERS infection status by patients' conditions is presented in Table 3. Of the 186 MERS patients, 36 died; 138 were leave from hospital; and 12 were under treatment.

Ordinary persons were very likely to die: 35 (97.2\%) out of 36 cases of death. The patients with the third infection were very likely to die: $29(80.6 \%)$.

\subsection{Association with Estimated duration of Contact with Super-spreader}

The association with the estimated duration of contact with a super-spreader is presented in Table 4. Believing that the MERS spread depended on the estimated duration of contact for the MERS patients, the duration of contact with the five super-spreaders (\#1, \#14, \#15, \#16, and \#76) was estimated.

Of the patients, super-spreaders caused infection as follows: \#1 infected 29 persons, \#14 infected 85 persons,

Table 3. MERS infection status by patients' conditions

\begin{tabular}{|c|c|c|c|c|}
\hline & \multicolumn{3}{|c|}{ Patient's condition(N: 186) } \\
\hline & & \multirow{2}{*}{$\begin{array}{c}\text { Death(N: 36) } \\
35(97.2)\end{array}$} & \multirow{2}{*}{$\begin{array}{c}\begin{array}{c}\text { Leave } \\
\text { hospital } \\
(\mathrm{N}: 138)\end{array} \\
104(75.4)\end{array}$} & \multirow{2}{*}{$\begin{array}{c}\begin{array}{c}\text { Treatment } \\
(\mathrm{N}: 12)\end{array} \\
8(66.7)\end{array}$} \\
\hline \multirow{4}{*}{$\begin{array}{l}\text { Patient } \\
\text { division }\end{array}$} & $\begin{array}{l}\text { Ordinary } \\
\text { person }\end{array}$ & & & \\
\hline & $\begin{array}{l}\text { Doctor/ } \\
\text { Nurse }\end{array}$ & - & $21(15.2)$ & $2(16.7)$ \\
\hline & Caregiver & - & $7(5.1)$ & $1(8.3)$ \\
\hline & $\begin{array}{l}\text { Medical } \\
\text { assistant }\end{array}$ & $1(2.8)$ & $6(4.3)$ & $1(8.3)$ \\
\hline \multirow{5}{*}{$\begin{array}{l}\text { Infection } \\
\text { stage }\end{array}$} & $\begin{array}{c}\text { Initial } \\
\text { infection }\end{array}$ & - & - & $1(8.3)$ \\
\hline & $\begin{array}{c}\text { Secondary } \\
\text { infection }\end{array}$ & $5(13.9)$ & $25(18.1)$ & - \\
\hline & $\begin{array}{c}\text { Third } \\
\text { infection }\end{array}$ & $29(80.6)$ & $87(63.0)$ & $8(66.7)$ \\
\hline & $\begin{array}{c}\text { Fourth } \\
\text { infection }\end{array}$ & $2(5.6)$ & $19(13.8)$ & $2(16.7)$ \\
\hline & Unidentified & - & $7(5.1)$ & $1(8.3)$ \\
\hline
\end{tabular}


Table 4. Association with estimated duration of contact with super-spreader

\begin{tabular}{|c|c|c|c|c|c|c|}
\hline & \multicolumn{5}{|c|}{ Super-spreaders } \\
\hline & & $\# 1^{*}$ & $\# 14^{* *}$ & $\# 15^{* * *}$ & $\# 16^{* *+*}$ & $\# 76^{* * * * * *}$ \\
\hline \multirow{5}{*}{$\begin{array}{c}\text { Estimated } \\
\text { duration of } \\
\text { contact }\end{array}$} & $\begin{array}{c}\text { May } 15-17, \\
2015\end{array}$ & $\begin{array}{c}20 \\
\text { persons }\end{array}$ & - & - & - & - \\
\hline & $\begin{array}{c}\text { May 27, } \\
2015\end{array}$ & - & $\begin{array}{c}47 \\
\text { persons }\end{array}$ & - & - & - \\
\hline & $\begin{array}{c}\text { May 27-29, } \\
2015\end{array}$ & - & - & $\begin{array}{c}3 \\
\text { persons }\end{array}$ & - & - \\
\hline & $\begin{array}{c}\text { May 28-30, } \\
2015\end{array}$ & - & - & - & $\begin{array}{c}10 \\
\text { persons }\end{array}$ & - \\
\hline & $\begin{array}{c}\text { June } 6 \text {, } \\
2015\end{array}$ & - & - & - & - & $\begin{array}{c}5 \\
\text { persons }\end{array}$ \\
\hline
\end{tabular}

* Number of cases of infection from \#1: 29person ${ }^{* *}$ Number of cases of infection from \#14: 85person

${ }^{* * *}$ Number of cases of infection from \#15: 6person ${ }^{* * * *}$ Number of cases of infection from \#16: 23 person

***** Number of cases of infection from \#76: 11person

\#15 infected 6 persons, \#16 infected 23 persons, and \#76 infected 11 persons. The number of the infection cases depended on the duration of contact with a superspreader.

\#1 infected 20 out of 29 persons during the estimated contact period between May 15 and 17, 2015. \#14 infected 47 out of 85 persons during the estimated contact period of May 27, 2015.

\#15 infected 3 out of 6 persons during the estimated contact period between May 27 and 29, 2015. \#16 infected 10 out of 23 persons during the estimated contact period between May 28 and 30, 2015.

\#76 infected 5 out of 11 persons during the estimated contact period of June 6, 2015.

\subsection{Association with Estimated duration of Contact with MERS-stricken Hospital}

The association with the estimated duration of contact with a MERS-stricken hospital is presented in Table 5. It is believed that the MERS spread depended on the estimated duration of contact for the MERS patients. Five hospitals-A, B, C, D, and E-were found to be vulnerable to MERS outbreak.

The MERS outbreak status in the five hospitals is as follows: Hospital A had 36 cases, Hospital B had 90 cases, Hospital C had 14 cases, Hospital D had 6 cases, and Hospital E had 5 cases. It is believed that MERS outbreak depended on the estimated duration of contact in each hospital.
Table 5. Association with estimated duration of contact with MERS-stricken hospital

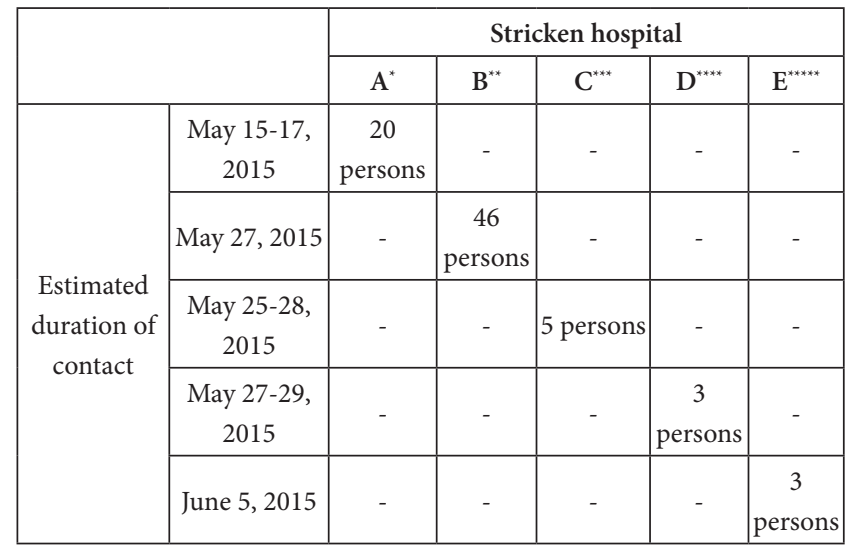

* Number of patients at Hospital A: 36person ** Number of patients at Hospital B: 90person

*** Number of patients at Hospital C: 14 person **** Number of patients at Hospital D: 6person

***** Number of patients at Hospital E: 5person

20 out of 36 persons were infected in Hospital A during the estimated contact period between May 15 and 17, 2015. 46 out of 90 persons were infected in Hospital B during the estimated contact period of May 27, 2015.

5 out of 14 persons were infected in Hospital C during the estimated contact period between May 25 and 28, 2015. 3 out of 6 persons were infected in Hospital D during the estimated contact period between May 27 and 29, 2015.

3 out of 5 persons were infected in Hospital E during the estimated contact period of June 5, 2015.

\subsection{MERS Outbreak Sites by Patient Division}

The MERS outbreak sites by patient division are presented in Table 6. Of the 186 MERS patients, ordinary persons formed $79.0 \%$, doctors/nurses $12.4 \%$, caregivers $4.3 \%$, and medical assistants $4.3 \%$.

Of the 186 MERS patients, ordinary persons were more likely to get infected with MERS in emergency rooms (73 persons; $39.2 \%)$, in the same ward $(44 ; 23.7 \%)$, and in the same room $(21 ; 11.3 \%)$. In particular, doctors/ nurses were more likely to get infected with MERS both in the same room and in the emergency rooms.

Patients are more likely to visit an emergency room than any other facility in a hospital when either an accident or an infectious disease occurs. For this reason, an emergency room is very likely to spread a pathogen during its latent period. It is therefore necessary to make more efficient guidelines for infectious disease patients' visiting emergency rooms and to reinforce relevant prevention. 
Table 6. MERS outbreak sites by patient division

\begin{tabular}{|c|c|c|c|c|c|}
\hline & \multicolumn{4}{|c|}{ Patient division(N: 186) } \\
\hline & & $\begin{array}{c}\text { Ordinary } \\
\text { person } \\
(\mathrm{N}: 147)\end{array}$ & $\begin{array}{c}\text { Doctor/ } \\
\text { Nurse } \\
\text { (N: 23) }\end{array}$ & $\begin{array}{c}\text { Caregiver } \\
(\mathrm{N}: 8)\end{array}$ & $\begin{array}{c}\text { Medical } \\
\text { assistant } \\
(\mathrm{N}: 8)\end{array}$ \\
\hline \multirow{11}{*}{$\begin{array}{c}\text { Outbreak } \\
\text { site: }\end{array}$} & Unidentified & $2(1.1)$ & - & - & - \\
\hline & Middle East & 1 & - & - & - \\
\hline & Same room & $21(11.3)$ & $1(0.5)$ & $5(2.5)$ & - \\
\hline & Same ward, & $44(23.7)$ & $10(5.4)$ & $3(1.6)$ & $1(0.5)$ \\
\hline & $\begin{array}{c}\text { Examination } \\
\text { based on } \\
\text { questioning }\end{array}$ & - & $3(1.6)$ & - & - \\
\hline & $\begin{array}{c}\text { Emergency } \\
\text { room }\end{array}$ & $73(39.2)$ & $7(3.8)$ & - & $4(2.2)$ \\
\hline & $\begin{array}{l}\text { Outpatient } \\
\text { clinic }\end{array}$ & $4(2.2)$ & - & - & - \\
\hline & Ambulance & - & $1(0.5)$ & - & $2(1.1)$ \\
\hline & Radiography & - & - & - & $1(0.5)$ \\
\hline & $\begin{array}{c}\text { Intensive care } \\
\text { unit }\end{array}$ & - & $1(0.5)$ & - & - \\
\hline & $\begin{array}{c}\text { Intrafamilial } \\
\text { infection }\end{array}$ & $2(1.1)$ & - & - & - \\
\hline
\end{tabular}

Table 7. Underlying disease in cases of death from MERS

\begin{tabular}{|c|c|c|c|}
\hline \multicolumn{2}{|c|}{} & $\begin{array}{c}\text { Underlying } \\
\text { disease* }\end{array}$ & Ranking \\
\hline \multirow{4}{*}{} & hypertension & 9 & 1 \\
\cline { 2 - 4 } & Cancer & 7 & 2 \\
\cline { 2 - 4 } & Asthma & 6 & 3 \\
\cline { 2 - 4 } $\begin{array}{c}\text { Underlying } \\
\text { diseases of } \\
\text { death }\end{array}$ & COPD & 3 & 4 \\
\cline { 2 - 4 } & Cardiac valve disease & 2 & 5 \\
\cline { 2 - 4 } & Hepatocirrhosis & 2 & 5 \\
\cline { 2 - 4 } & Diabetes mellitus & 2 & 5 \\
\cline { 2 - 4 } & Others & $\begin{array}{c}13(\text { Each } \\
1 \text { case })\end{array}$ & 9 \\
\hline
\end{tabular}

* Underlying disease in 24 out of 36 cases of death

* 46 cases of underlying diseases, including overlap ones

\subsection{Underlying Disease in cases of Death from MERS}

The underlying diseases in the cases of death from MERS are presented in Table 7. 24 out of 36 cases of death had an underlying disease. The 24 cases involved 21 underlying diseases. A total of 46 cases involved underlying diseases, including overlap ones.
The most frequent underlying disease was hypertension (9 cases), followed by cancer (7) and asthma (6).

\section{Discussion}

The purpose of this study was to analyze the problems with infectious diseases on the basis of the MERS spread in South Korea. For this purpose, the data concerning the daily status of MERS, as released by $\mathrm{CDC}^{6}$ and $\mathrm{MOHW}^{7}$, and those released by $\mathrm{KBS}^{8}$ supervising disaster broadcasting at the national level were used. The occurrence of super-spreaders and MERS-stricken hospitals depended on the estimated duration of contact. The infection was more likely to be at the third stage and some cases were "unidentified" in terms of the infection stage; thus, the infection-related disaster path analysis and management system was inefficient. The fact that the infection stage for 36 (19.3\%) out of 186 MERS cases was not determined seems to be another problem with infection-related disasters. The infection was very likely to occur in emergency rooms. It is therefore necessary to develop a system for emergency medical providers' preventing and managing infection-related disasters.

According to $\mathrm{CDC}^{5}$, a super-spreader refers to the one who has infected $\geq 4$ persons. The super-spreaders infecting $\geq 4$ persons were $\# 1, \# 14, \# 15$, \#16, and \#76. While CDC $^{5}$ reported that \#1 infected 28 persons with MERS, this study found that \#1 infected 29 persons. There was such a gap in the number of the infection cases. It is because this study used the data concerning the daily status of MERS, as released by $\mathrm{CDC}^{6}$ and $\mathrm{MOHW}^{7}$, and those released by $\mathrm{KBS}^{8}$ supervising disaster broadcasting at the national level.

After the initial MERS outbreak in Middle East ${ }^{9-12}$, conducted research on MERS. In contrast, little research on the infectious disease of MERS was conducted in South Korea, which is not considered as a Middle Eastern region. In this context, a person who visited Middle East and returned to South Korea rapidly spread the MERS pathogen. It is believed that the MERS outbreak has brought changes to awareness of infection-related disasters.

$\mathrm{Kim}^{13}$ contended that the immediate cause of the MERS crisis was the failure of the government to cope with it at its initial stage. The government refused to hurry to reveal the name of hospitals with MERS or close the central originator. The failure to cope with it at its initial stage was due to poor expertise and the absence of leadership in 
the control tower. It is also caused by the environment in the emergency rooms as well as by family-caring culture ${ }^{14}$ reported that the super-spreader \#14 infected as many as 83 persons. The period of contact with \#14 was estimated to be between May 27 and 29. This study found that \#14 infected 84 persons. The exposure was very likely to occur on May 27 during the estimated contact period.

${ }^{15}$ mentioned the law concerning infectious disease prevention and management and indicated problems with quarantine and isolation measures ${ }^{16}$ indicated that the MERS crisis was related to the geographical background, spatial spread, infectious disease outbreak and spread, and the problems with hospitals ${ }^{17}$ noted that the MERS outbreak brought changes to the pattern of using public transportation.

The MERS outbreak in South Korea has changed the awareness of infection-related disasters and revealed the problems in coping with the infection-related disaster. It is necessary to improve planning, management, and prevention of infection-related disasters as well as hospital culture, activate the emergency medical service system, and make institutional reinforcement, including information disclosure.

Despite its significance, this study has some limitations: first, it only used the data concerning the daily status released by $\mathrm{CDC}^{6}$ and $\mathrm{MOHW}^{7}$ and those released by $\mathrm{KBS}^{8}$ supervising disaster broadcasting at the national level; second, healthcare authorities failed to disclose information completely; third, it set the period until July 28, not the date of the end to MERS outbreak. Care should be taken to generalize the results of this study on MERS.

\section{Conclusions}

This study aimed to identify problems with infectious diseases on the basis of the spread of MERS. Five superspreaders of MERS contributed to more than a half of infections with the disease. It is necessary to actively develop systematic management systems that involve planning, implementation, restoration, and prevention with the aim of coping with infectious disasters. It is also necessary to conduct research on prevention and management of a diversity of infectious disasters.

\section{References}

1. World Health Organization (WHO). Middle East respiratory syndrome coronavirus (MERS-CoV) [Internet]. [Cited
2015]. Available from: http://www.who.int/csr/disease/ coronavirus_infections/faq_12_jun_2015/en/.

2. Zaki AM, van Boheemen S, Bestebroer TM, Osterhaus AD, Fouchier RA. Isolation of a novel coronavirus from a man with pneumonia in Saudi Arabia. The New England Journal of Medicine. 2012; 367(19):1814-20.

3. Reusken CBEM, Haagmans BL, Muller MA, Gutierrez C, Godeke Gert-Jan,Meyer B, Muth D, Raj VS, Smits-De Vries L, Corman VM, Drexler Jan-Felix, Smits SL, Tahir YEEl, De Sousa R, van Beek J, Nowotny N, Maanen K van, HidalgoHermoso E. Bosch Berend-Jan Rottier P, Osterhaus A, Gortazar-Schmidt C, Drosten C, Koopmans MPG. Middle East respiratory syndrome coronavirus neutralizing serum antibodies in dromedary camels: a comparative serological study. The Lancet Infectious Diseases. 2013; 13(10):859-66.

4. Assiri Al, McGeer A, Perl TM, Price CS, Al Rabeeah AA, Cummings DA, Alabdullatif ZN, Assad M, Almulhim A, Makhdoom H, Madani H, Alhakeem R, Al-Tawfiq JA, Cotten M, Watson SJ, Kellam P, Zumla AI, Memish ZA. KSA MERS-CoV investigation team. Hospital outbreak of Middle East respiratory syndrome coronavirus. The New England Journal of Medicine. 2013; 369(5): 407-16.

5. Korea Centers for Disease Control and Prevention(CDC). Middle East respiratory syndrome coronavirus outbreak in the Republic of Korea. Osong Public Health and Research Perspectives. 2015; 6(4):269-78

6. Korea Center for Disease Control \& Prevention (KCDCP). MERS. [Internet]. [Cited 2015]. Available from: http:// mers.go.kr/mers/html/jsp/main.jsp.

7. Ministry of Health and Welfare (MOHW). Daily Status of MERS [Internet]. [Cited 2015]. Available from: http://www. mohw.go.kr/.

8. Korean Broadcasting System (KBS). Actual condition of mers infection, to see at a glance [Internet]. [Cited 2015 Aug 06]. Available from: http://dj.kbs.co.kr/resources/2015.

9. De Groot RJ, Baker SC, Baric RS, Brown CS, Drosten C, Enjuanes LM. Fouchier RA, Galiano M, Gorbalenya AE, Memish ZA, Perlman S, M. Poon LL, Snijder EJ, Stephens GM, Woo PCY, Zaki AM, Zambon M, Ziebuhr J. Middle East respiratory syndrome coronavirus (MERS-CoV): Announcement of the coronavirus study group. American Society for Microbiology Journals. 2013; 87(14):7790-2.

10. Drosten C, Seilmaie M, Corman V, Hartmann W, Scheible G, Sack S, Guggemos W, Kallies R, Muth D, Junglen S, Müller M, Haas W, Guberina H, Röhnisch T, SchmidWendtner M, Aldabbagh S, Dittmer U, Gold H, Graf P, Bonin F, Rambaut An, Wendtner CM. Clinical features and virological analysis of a case of Middle East respiratory syndrome coronavirus infection. The Lancet Infectious Diseases. 2013; 13(9):745-51. 
11. Memish ZA, Zumla AI, Al-Hakeem RF, Al-Rabeeah AA, Stephens GM. Family cluster of Middle East respiratory syndrome corona virus infections. The New England Journal of Medicine. 2013; 368(26):2487-94.

12. Assiri A, Al-Tawfiq JA, Al-Rabeeah AA, Al-Rabiah FA, Al-Hajjar S, Al-Barrak A, Flemban H, Al-Nassir WN, Balkhy HH, Al-Hakeem RF, Makhdoom HQ, Zumla AI, Memish ZA. Epidemiological, demographic, and clinical characteristics of 47 cases of Middle East respiratory syndrome coronavirus disease from Saudi Arabia: a descriptive study. The Lancet Infectious Diseases. 2013; 13(9):752-61,

13. Kim ES. A social analysis of the limitation of governmental MERS risk communication. Korean Review of Crisis \& Emergency Management. 2015; 11(10):91-109.
14. Kim SG. Healthcare workers infected with Middle East respiratory syndrome coronavirus and infection control. Journal of the Korean Medical Association. 2015; 58(7):647-54.

15. Park MJ, Lee JK. A study on legal problems and proposal for an enactment regarding MERS in the Republic of Korea. Korean Association of Medical Law. 2015; 23(2): 191-209.

16. Choi BD. Geography of MERS outbreak and politics of biopower. Journal of Society of Space. 2015; 25(3):173-92.

17. Jeong KD, Yoon YK, Seo JS, Im PJ, Sin SW. A study on urban railway passenger's safety strategy for emergency: a focus on the MERS case. Korean Society for Railway (Autumn Conference). 2015; 10(4):1357-62. 